April 2008

\title{
The Three "Switches" of Identity Construction in Genocide: The Nazi Final Solution and the Cambodian Killing Fields
}

Maureen S. Hiebert

Follow this and additional works at: https://digitalcommons.usf.edu/gsp

\section{Recommended Citation}

Hiebert, Maureen S. (2008) "The Three "Switches" of Identity Construction in Genocide: The Nazi Final Solution and the Cambodian Killing Fields," Genocide Studies and Prevention: An International Journal: Vol. 3: Iss. 1: Article 3.

Available at: https://digitalcommons.usf.edu/gsp/vol3/iss1/3

This Articles is brought to you for free and open access by the Open Access Journals at Digital Commons @ University of South Florida. It has been accepted for inclusion in Genocide Studies and Prevention: An International Journal by an authorized editor of Digital Commons @ University of South Florida. For more information, please contact digitalcommons@usf.edu. 


\title{
The Three "Switches" of Identity Construction in Genocide: The Nazi Final Solution and the Cambodian Killing Fields
}

\author{
Maureen S. Hiebert \\ Centre for Military and Strategic Studies \& Department of Political \\ Science, University of Calgary
}

\begin{abstract}
If we want to understand why political elites choose to commit genocide, we need to inquire into how elite perpetrators reconstruct the collective identity of the victim group such that genocide becomes the only possible policy option. This article argues that elites decide to commit genocide, and not some other less catastrophic policy of repression or violence, when three conceptual "switches" concerning the identity, interests, and future actions of the victim group are "turned on" by the perpetrators. First, members of the victim group lose their (often marginal) status within the political community and are constructed as outsiders, to whom rights and obligations are no longer owed. Next, they come to be seen as dangerous enemies whose continued physical presence is seen to pose an overwhelming threat to the political community. This second mortal-threat conception consists of three mortal-threat "motifs": the struggle between the perpetrator and victims as an epic battle; the victims as the controlling force behind, or controlled by, powerful threatening external forces; and the victims as carriers of deadly biological contagion. Finally, the victims are viewed as subhumans who can be killed without compunction. The process of identity reconstruction as a whole is underpinned by a pre-genocide history of exclusionary and authoritarian intergroup norms and practices, and of authoritarian approaches to conflict management, and is triggered by serious economic, political, or security crises.
\end{abstract}

Keywords: genocide, identity, constructivism, Holocaust, Cambodian genocide

\section{Introduction}

For genocide scholars, the overriding research question is, Why does something so terrible as genocide happen (and continue to happen)? Given the enormous scope of the question and the problems associated with grand theorizing in the social sciences, ${ }^{1}$ one way to at least partially answer this larger question is to attempt to answer several smaller ones: What are the underlying conditions that lead to genocide? Why are certain groups identified as targets? Why do bystanders allow the killing to occur? Why do the perpetrators do what they do? and so on. This article deals with another smaller but central question: Why do political elites choose a policy of genocide instead of some other less catastrophic and irrevocable policy?

As several genocide scholars have noted, the genocides of the twentieth and twenty-first centuries have often been preceded by serious destabilizing security, economic, or political crises with which the eventual victims of genocide come to be negatively identified. ${ }^{2}$ If we want to know why genocide against a specific group or groups becomes the policy option of political elites in the wake of crisis, we need to think through carefully the way in which genocidal political elites and the dominant

Maureen S. Hiebert, "The Three "Switches" of Identity Construction in Genocide: The Nazi Final Solution and the Cambodian Killing Fields." Genocide Studies and Prevention 3, 1 (April 2008): 5-29. (C) 2008 Genocide Studies and Prevention. doi: 10.3138/gsp.3.1.5 
society reconceptualize the victim group's identity, interests, and potential actions as a response to crises. I argue here that elite conceptions of the victim group that culminate in genocide go beyond identifying the victim group as being to blame for specific crises (the scapegoat theory) or as a general threat to the future well-being of the political community. If the collective identity-construction process stops at this point, the policy response is likely to be anything from the arrest and repression of the group's cultural, political, or economic elite to restrictions on members' economic, political, or cultural activities. More seriously, elites may choose to use violence to encourage flight or to terrorize the group into submission, or they may use large-scale population-control measures such as physical segregation, internal deportation, or expulsion, as well as retributive massacres. State-sponsored violence, terror, forced population movements, and, of course, mass killing are, to be sure, often part of the genocidal process itself. But in genocide they are specific policies designed to achieve the larger policy goal of physically liquidating all or a part of the victim group; they are not stand-alone policies believed by elites to be sufficient to counter the real and perceived threats posed by a specific group.

The central claim being made here is that the reconstruction of the identity, interests, and future actions of the victim group that leads to specifically genocidal policies consists of a more precise formulation of the threat the victim group is believed to pose. Fundamental to the reconceptualization process is the emergent belief that the victim group imperils the dominant community through the mere fact of its continued physical existence. Because the existence of the victim group is perceived to be the ultimate source of the threat menacing the political community, the physical liquidation of the victim group is understood by political elites (and accepted by the dominant society) as the only way to protect society, truly and definitively, from a pernicious and threatening "enemy within." Without this specific reconceptualization process, the response to crises would be other, less catastrophic forms of state violence, repression, or conflict in which the victim group is stripped of real material power but not of the lives of the members of the group.

To understand how political elites arrive at this specific reconceptualization of the victim group, I begin by unpacking the mutually reinforcing and constitutive relationship between structures and elite agency and then show how this relationship influences the process by which elite political actors choose to initiate and execute genocide. The article then examines what are called, in this study, the three conceptual "switches" regarding the victim group-as foreigners, as mortal threats, and as subhumans-that must be "turned on" in order for genocide to happen. The final section provides a brief illustration of the argument with reference to two relatively dissimilar cases of genocide: the Nazis' Final Solution against the Jews of Europe (a "racial"/ethnic genocide) and the Cambodian genocide (a political/revolutionary genocide). ${ }^{3}$

\section{Genocide as a "Rational Choice"}

On the face of it, genocide as a response to a crisis and a perceived threat to society is not only evil but irrational. Reasonable human beings would rightly ask why the Nazis, the Khmer Rouge, the Young Turks, or the Hutu Power regime chose to destroy whole groups of people in response to real and perceived threats, to exterminate men, women, and children simply because of who they were. It is an act that seems to rest on entirely irrational prejudices, fears, and suspicions. But, as Helen Fein suggests, genocide is, from the perspective of the perpetrators, an apparently "rational choice"-a 
"goal-oriented act [that] is rationally instrumental to their ends." ${ }^{4}$ Genocide is a rational choice not because of the ideas or perceptions upon which it is based but because of the decision-making process that leads to its perpetration.

In a recent example of an attempt to explain genocide as a rational, goal-oriented strategic policy, Benjamin Valentino contends that elites commit genocide in order to realize radical policy goals. In pursuit of these wider policy goals, perpetrator elites employ exterminatory policies against a target group to force its members to do something they would otherwise not do that is required for the realization of these policies-for example, to submit to a radical new way of life, to give up their homes and possessions, to cease supporting political and military opposition groups-or to counter threats posed by a group. This decision, for Valentino, is made only when leaders have concluded that other options for achieving their ends, including less violent forms of repression or limited concessions to victim groups, are ineffective or impractical. ${ }^{5}$ Valentino further suggests that what he calls "ethnic mass killing" 6 takes place when elites believe that the victims "pose a threat that can be countered only by physically removing [them] from society."7

Leaving aside Valentino's assertion that genocide is a means to a strategic end rather than a policy goal in and of itself (a position that has been the subject of much debate among genocide scholars for some time), his argument concerning conceptions of threat and the decision to commit genocide is convincing, but it does not go far enough. Neither the general perception of threat attributed to the victim group nor the failure of less drastic policies directed at specific groups to realize other policy goals is, on its own, enough to explain why genocide specifically is the policy response of radical political elites, rather than other forms of violence and repression. We need to go further and inquire into how elites construct the identities of their victims such that genocide becomes the only policy option.

Another possible approach to explaining why and how political elites make the rational but horrible choice to commit genocide is rational choice theory. As an exclusively agency-oriented explanation of political behavior, rational choice theory argues that actors choose between sets of goals; that goals are "ordered by purposive actors"; that the possible choices that actors might make are only those known to the chooser; that actors try to choose the best means to their ends; that means themselves are chosen through a process of calculating "subjective expected utility"; and that "intentions can be inferred from behaviour." "Significantly for the present study, rational choice theory does not inquire into how actors arrive at their intentions or goals. Rational choice theorist William H. Riker argues that linking intentions to prevailing social norms or structures is an "unnecessary convolution that complicates but does not eliminate the rational choice model," because social norms "are themselves creations of actors for some purpose," elements that actors choose from to frame their intentions and make their choices. 9

Using a rational choice approach, we might argue that genocide (the observed behavior of a state or comparable authority) is simply based on the intention to respond to a crisis or set of crises and to meet a threat posed to the political community. But without examining how genocidal elites arrive at this intention, and what precisely underpins it, we have no way of knowing why genocide, and not some other, less horrific form of repression or violence, is the response to crisis. All that rational choice theory can tell us is that intentions are connected to goals and that purposive actors act to achieve their goals, based on a set of expected utility calculations that genocidal elites may follow in making the choice to commit genocide. ${ }^{10}$ Riker's understanding of social 
norms or structures as simply the outcome of previous choices by actors misses the possibility that agents' actions consciously shape social norms and structures only part of the time - that is, that actors do not stand apart from ideational or material structures and simply pick and choose which elements of structure, such as norms, beliefs, and practices, will influence their intentions and goals. Missing in rational choice explanations is the mutually constitutive nature of structure and agency and, therefore, the crucial ideational content that informs a choice to commit genocide as opposed to some other act.

The missing content can be filled in by examining the interrelationship between structure and agency-specifically, how the mutually constitutive relationship between structure and agency affects how genocidal elites come to reconstruct the interests, identity, and future actions of the victim group.

\section{A Constructivist Explanation}

As several genocide scholars have pointed out, modern genocides are motivated in part by ideas. Robert Melson argues, for example, that revolutionary ideologies and the revolutions they inspire call for the radical restructuring of society and the exclusion of whole groups of people who are defined either as outside the new revolutionary order or as fundamental threats to it. ${ }^{11}$ Similarly, Eric Weitz suggests that genocidal ideologies are founded on modern exclusionary conceptions, such as nation, race, social Darwinism, eugenics, hygiene, and imperialism, that have been combined in lethal ways by genocidal elites to create ideologies that variously espouse the superiority of specific races, the need for ethnically homogenous nation-states, the imperative of protecting one's own race from contamination by other races, and, in the case of communism, the overthrow of exploitative economic systems and the socioeconomic groups that dominate these systems. ${ }^{12}$ As Alex Alvarez also shows, such ideologies are used by genocidal elites to manipulate state institutions and ordinary people alike to target specific groups for elimination. ${ }^{13}$

Arguments that emphasize ideology are important, because they help identify why genocidal regimes pinpoint certain groups as either superfluous or dangerous and in need of removal from the new revolutionary order. But what ideology on its own cannot explain is why genocide becomes the policy, rather than economic marginalization, physical segregation, or expulsion. Weitz, for example, lays out in great detail the origins of Nazi racist ideology but, in his treatment of the Holocaust, does not explain why the same ideology singled out the Jews for complete extermination while the Poles were slated for perpetual servitude. In short, the same ideology produced two difference policy outcomes for two separate groups.

While acknowledging the importance of ideology in the overall genocidal process, we need to examine the importance of ideas-particularly shared cultural and political norms, beliefs, and historical practices-in a slightly different way if we want to understand how it is that elites come to choose genocide as a policy option. Specifically, we need to concentrate on how genocidal elites come to construct the identities of their victims and how this identity construction is influence by pre-genocide norms, beliefs, and practices. How elites construct the identities of groups in society determines whether genocide or some other form of repression or violence becomes the policy of the state. To be sure, the motivations to commit genocide for mid-level officials and frontline killers, although influenced by elite conceptions of the victim group and by the same set of shared exclusionary norms and practices that inspire elite actors, are not identical to those of senior decision makers. Christopher Browning's research into the 
evolution of the Nazi Final Solution, for example, shows that "desk killers" of various ranks were driven by a variety of imperatives, from bureaucratic infighting to career advancement, ${ }^{14}$ while social psychologist James Waller argues that the ordinary people who actually do the killing do so because of the all-too-human socialpsychological tendency to acquiesce to authority and the perceived requirements of group solidarity, to allow killing to become routinized over time, and to see members of out-groups as competitors or threats. ${ }^{15}$

Drawing on constructivist social theory, international relations theorist Alexander Wendt argues, in his self-described meta-theory of collective identity construction, that the subjective understanding of a group's identity is influenced not only by formal political and economic organizational arrangements, and by the material distribution of power capabilities between collective actors, but also by knowledge and practices. $^{16}$ Wendt suggests that material and ideational structures broadly construed, not just political ideologies, shape conceptions of identities and interests, as well as behavior, not only among members of one's own group but with respect to other groups. Collective identities are thus constructed and reconstructed according to collective understandings of the "self" and "other." Meanwhile, conceptions of the "reality" of intergroup relations are also socially constructed, such that new sets of mutual understandings, expectations, knowledge, and perceived interests regarding different groups can either change or solidify over time and thus, in turn, can change or solidify certain intergroup relationships and actions. ${ }^{17}$

For Wendt, the structure of social consciousness-what he terms the "distribution of ideas or knowledge"-is shared among actors in the form of norms, rules, or institutions. Social and ideational structures constitute identities and interests, helping actors to, for example, find common solutions to problems, define expectations of behavior, and identify what constitutes a threat. ${ }^{18}$ I argue here that in genocide, the "distribution of ideas" is composed of formalized rules and practices of exclusionary and unequal group interaction, exclusionary norms concerning conceptions of the community, and authoritarian methods of conflict management that exist prior to the genocide. These pre-genocide practices, norms, and ideas, in turn, serve as the lens through which the meaning of crises is interpreted, namely, as the responsibility of the victim group, such that the victim group is believed to pose a general threat to the political community in the future. Exclusionary practices and norms also function as the material and ideational foundation upon which rests political elites' further reconstruction of the collective interests, identities, and behavioral expectations of the victim group as a mortal threat to the continued survival of the race, revolution, or nation.

As for how the "rational choice" to commit genocide is made, we must inquire into how preferences are constituted, because, as Wendt tells us, "we want what we want because of how we think about it."19 Motivations, desires, or interests should be seen as "schemas," "scripts," "frames," or "representations," which are knowledge structures that make possible "the identification of objects and events." ${ }^{20}$ How elites think about a crisis and specific groups in society and how they come to reframe the identity, interests, and future actions of the victim group are part of a pattern of symbolic interaction in which collective actors relate to one another on the basis of the meaning they have given to one another and to the specific acts they perform. These meanings themselves stem from how the broader situation is understood, which, in turn, is itself "embedded in culture." ${ }^{21}$ Actors revise their definitions of the situation as they learn more about each other through continued social interaction. In situations in 
which power capabilities are uneven-as is clearly the case between the perpetrators and the victims of genocide- "social acts... tend to evolve in the direction favored by the more powerful." 22

Wendt argues that, like individual actors, collective actors engage in "perspective taking" (i.e., cognitively standing in the others' shoes) to further define each other's identity and interests. Through a process of shared interaction, Ego shapes a conception of Alter that may or may not be objectively correct. Incorrect interpretations of the identity and interests of Alter are not, however, the result of incomplete information about Alter or of misinterpretations of the "facts" about Alter, as rational choice theory would suggest. Instead, emerging perceptions of Alter, no matter what they are, are not passive perceptions of something that exists independent of Ego

but actively and over time constitutive of Alter's role vis-à-vis Ego. Through her representational practices Ego is saying to Alter, "you are an X, and I will act toward you as if you were an X." To that extent who Alter is, in this interaction, depends on who Ego thinks Alter is... Role-identities are the meanings that actors attribute to themselves when seeing themselves as an object, that is, from the perspective of the Other. To that extent who Ego is, in this interaction, is not independent of who Ego thinks Alter thinks Ego is... These self-understandings are in one sense inside Ego's own head, but they only become meaningful in virtue of Alter confirming them, which is to say in virtue of social relations. ${ }^{23}$

Playing the role of Wendt's "Ego," genocidal political elites take the perspective of "Alter"- that is, the victim group-such that the latter is believed to see in the state and the dominant society a community that will be or is already covertly under the group's control, and/or a vulnerable society that can be exploited and ruined, to the victim group's advantage. Perpetrator elites, in effect, say to the victim group, "Your continued existence is a mortal threat to our continued survival, and we expect you to act as such a threat, and we will act toward you as if you were a mortal threat." For genocidal elites, the victim group's identity is that of a mortal threat, because elites think the group is a mortal threat.

This "perspective" is not, of course, the real perspective of the victim group but a socially constructed one, based on perceptions rooted in pre-genocide exclusionary norms and practices and in the interpretation of crisis. When political elites contemplate genocide in the wake of crises, they do not, of course, begin a brandnew process of social interaction with the victim group. Rather, the process of symbolic interaction through perspective taking is a continuation of the social interaction between elites and the dominant society, on the one hand, and the eventual victim group, on the other, that has been going on for years but is now pursued in a more urgent and malevolent fashion.

The conceptual possibility of coming to see the victim group's existence as a mortal threat is grounded in widely held and entrenched pre-genocide norms and practices marked by an unequal and exclusionary relationship between the victim group and rest of society; in the tendency for groups in society to engage in informal sectarian associational arrangements; in a conception of the political community that views the victim group as outside or marginal to "true" or "authentic" membership in the community; and in a state with a history of seeing societal conflicts-including those involving the victim group-as serious threats to the stability of the state and society that must be countered with repression, exclusion, and possibly force. Crises serve to animate the worst existing conceptions of the victim group as well as to create an extremist context in which political elites search for a way to understand the situation 
they are in, to bring the crisis or crises to a conclusion, and to prevent such crises in the future. ${ }^{24}$ Turning to an already suspect group, elites engage in a renewed process of interaction through perspective taking with the eventual victims of genocide. Drawing on existing conceptions of the group and a recent history of disruptive crises, elites read into the identity, interests, and future actions of the victim group a new and more powerful threat to the community that can be solved only through deadly "final solutions" to what are presented as perennial, and now urgent and deadly, "problems."

By comparison, in non-genocidal situations, either the response to crises includes no reconceptualization of the identity and future behavior of groups in society, or the reconceptualization process does not involve seeing the continued physical presence of a specific group as an overwhelming threat. In the former situation, crises are accompanied by a conceptualization process in which different groups within the political community continue to be seen as full members of that community, with commonly held rights and obligations vis-à-vis each other and the state and shared goals for the future. Cooperation or, at least, accommodation in the face of internal or external crises, whether economic, political, or military/security, is the result. The political community, while in some instances still heterogeneous, is nonetheless conceived of by elites and by members of society as a whole as one political community to which all members of society still belong. Here the collective self is conceptualized as inclusive, such that there is no other; a collective self thus confronts crisis as a unified whole. Unlike genocidal situations, such cases are characterized by intersubjective understandings of society based on an existing political culture of tolerance and inclusiveness.

In instances where non-genocidal state violence, repression, or intergroup conflict is the result of crises-for example, the Spanish Civil War-membership in the political community may become contested at the same time that there is an absence of common goals within the larger political community. The groups involved, whether they be ethnically, religiously, linguistically, economically, or politically defined, see each other as competitors for economic, political, military/security, territorial, or social goods in the present and possibly even as threats to group gains in the future. While the important element of threat and fear for the future also occurs in genocide, non-genocidal conflict situations produce intergroup conflict because the threat posed by competing groups is perceived to be mutual and is derived from actually existing power capabilities, not from the mere fact of a group's physical existence. Conflict between groups or state-sponsored repression is pursued in order to weaken a competitor group, to acquire the group's capabilities, or to subordinate or even repress members of the group so that one's own group or the state may reap the benefits of having acquired the adversary's power capabilities (e.g., territory, economic and political power) for present and future gain and protection.

Like cases of genocide, situations of mutual conflict are marked by a conceptualization of the collective self and other in which a relatively strict boundary is drawn between the competing groups. Intergroup conflict is also frequently underpinned by exclusionary and authoritarian norms and practices. But such situations differ from genocide in that each group does objectively maintain some kind of real power capability and that the contest itself is, for the most part, over real things and, therefore, is not a purely constructed one.

\section{Constructing Victims: The "Three Switches" of Genocide}

The collective identity reconceptualization process that leads to genocide involves three discernible yet often overlapping switches that must be turned on in order for genocide 
to occur. What sets this process apart from situations of mutual conflict and from the exercise of non-genocidal state violence is the conceptualization of the victim group as a powerful and dangerous "enemy within" whose overwhelming power is believed to derive from their physical existence. The three switches are (1) the identification of the victim group as outside or foreign to the political community; (2) the identification of the victim group as an almost superhumanly powerful, dangerous "enemy within" whose continued existence threatens the very survival of the political community; and (3) the paradoxical identification of the victim group as subhuman.

The first switch in the process revolves around the definition of who lies within and outside the political community or what Helen Fein calls the universe of reciprocal obligations. ${ }^{25}$ The function of this conceptualization is to delineate clearly to whom political, economic, and social rights and obligations are owed, including citizenship, constitutionally recognized political rights, socioeconomic support, and participation in the economy. Those who are conceptualized to lie outside the political community are deemed not to be entitled to such obligations and are, therefore, reconceptualized from marginalized insiders to non-members or "foreigners." A strict boundary is drawn between "us" and "them," or the collective "self" and the alien "other." This boundary is similar to that drawn between competitor groups in situations of intergroup conflict but goes much further, in that membership in the political community is no longer contested by competing groups, as is the case, for example, in civil wars. Rather, the victim group is unilaterally stripped of membership, first conceptually and then practically, by the state and the dominant society. No longer part of the community, the victim group is effectively removed from society, and thus from protection by their (former) fellow citizens against a hostile state.

The second switch in the genocidal conceptual process is the one that is entirely unique to genocide. The now "foreign" victim group is further reconceptualized as a powerful enemy bent on the destruction of the dominant group. Crucially, the source of this power and threat is believed to reside, ultimately, with the physical presence of the victim group. The continued existence of the victim group thus portends great danger for the very survival of the wider community and produces, as Daniel Chirot and Clark McCauley note, an intense "fear of extermination." 26 The history and future of the political community are reconstructed as an epic battle between a virtuous "us" and an alien, subversive, inherently threatening "enemy within." Claims regarding the supposed economic, political, or other manifestations of the victim group's power are regularly asserted, but the actual resources or power capabilities possessed by the victim group are dwarfed by those held by the perpetrator state and the dominant society. Objectively, the victim group does not pose a credible threat to the dominant society. Because it is believed that the victim group derives its overwhelming power from the members' physical existence, and not from substantive power capabilities, conflict, or repression-in which real power capabilities could potentially be removed from a threatening group-is not enough; to neutralize the perceived threat posed by the victim group, its members must be physically eliminated in order to rid the group of the true source of its power. As psychologist Robert Jay Lifton concludes in his study of Nazi doctors at Auschwitz, "where the threat is so absolute and so ultimate...genocide becomes not only appropriate but an urgent necessity." ${ }^{27}$ Lifton continues, "thus perceived as an absolute threat to the continuous life of one's own people, the victim group is seen as the bearer of death and therefore the embodiment of evil. More than merely nonhuman or heathen, it is dangerously anti-man and antiGod. Its disease takes the form of infecting others with death taint and deadly 
weakness ... Only genocide, total elimination of the disease will protect one from that weakness." Because the victim group "threatens one's own people with extinction ... one must absolutely extinguish him first." 28

More specifically, the second-switch conception of the victim group is grounded in, and expressed as, three mortal-threat "motifs" in which the very survival of the political community is perceived by political elites to be at stake. The first motif is that of "epic struggle," in which elite perpetrators believe that they are engaged in a battle to the death-a "race war" or "class conflict," for example-with their victims. Victory requires the physical liquidation of the threatening victim group, whose own victory is thought to result in the destruction of the race, nation, or revolution. The second threat motif is that of pernicious foreign ideological or national influence or invasion. For some perpetrators, this conception involves linking the extermination of the victim group with the need to save the political community from threatening external actors who are believed to be under the victim group's control. For other perpetrators, "internal enemies" are targeted because of their supposed links to expansionist or powerful external actors. Finally, the third threat motif is expressed as a disease metaphor. According to this perception, the victims must be physically eliminated because their continued existence is believed to expose the perpetrators and the wider society to lethal contagions. Perceived as "microbes," "bacteria," or "cancer," members of the victim group are to be killed through violent processes of "purification," "cleansing," and the surgical "cutting out" of diseased parts.

The dehumanization of the foreigner-cum-dangerous-enemy-within is the final switch of the genocidal reconceptualization process. This conceptualization of the victim group is not the motivation for genocide, as much of the existing genocide literature suggests, but, instead, provides an understanding of the victim group that is necessary in order for the actual extermination to take place. The dehumanization of the victim group is not enough to lead to genocide, because to see members of a particular group as subhuman is not to impute to them the capacity or the power to constitute an overwhelming mortal threat. The Nazis, for example, regarded Poles and other Slavs as Untermenschen, as less-than-human beings to be repressed and transformed into slave laborers for the Third Reich and the new German East. Here only the third switch was turned on. Jews, on the other hand, were regarded as mortal threats who, because of the very fact of their existence, had to be exterminated.

Victims of genocide are nonetheless dehumanized by being equated with "animals," "vermin," or "pests," so that the actual act of exterminating whole groups of people becomes intellectually comprehensible and psychologically tolerable for perpetrators and bystanders alike. Whereas the mortal-threat conceptualization (the second switch) provides the motivation and rationale for genocide, dehumanizing the victim group makes the actual genocide psychologically palatable and, therefore, makes its perpetration possible. As Herbert Kelman argues, dehumanization in a genocidal context is one of the processes by which the "usual moral inhibitions against violence become weakened." Such an understanding of the target group creates a situation in which "moral principles no longer apply to the victim," thus facilitating smooth and efficient killing, as moral restrictions are more easily overcome. ${ }^{29}$

\section{The Nazis' Final Solution and the Cambodian Killing Fields}

What follows is a necessarily brief analysis of the three switches with reference to the Final Solution and the Cambodian Killing Fields. Rather than a chronological narrative of each genocide or a detailed examination of the available historical 
evidence regarding exactly when and how the decision to commit genocide was made, the discussion will focus on a few key illustrations of how elite perpetrators reconceptualized the identity of their victims in such a way that they came to consider genocide the only acceptable policy option.

\section{The First Switch}

The first conceptual switch for Germany's Jews was turned on by Adolf Hitler and his victorious National Socialist German Workers' Party (NSDAP) shortly after they came to power in January 1933. Central to the Nazi conception of German Jews at this time was the idea that Jews were inherently foreign and that a strict boundary must be drawn between the alien, corrupting "Jew" and the German, or "Aryan," majority. Hitler saw conceptually and practically stripping German Jews of their "Germanness" as key to achieving the völkisch ideal of a strong, homogeneous, and united Germany free of destructive Jewish influence. Looking back on the first years of Nazi leadership, Hitler made plain this conception of German Jews, urging in his closing speech at the Nuremberg Parteitag on 12 September 1938 that the removal of German Jews from all facets of German society must continue, "because National Socialism desires to establish a true community of the people... Because we are National Socialists we can never suffer an alien race which has nothing to do with us to claim the leadership of our working people."30 More than a year earlier, Hitler similarly argued, in a speech before the Reichstag on 30 January 1937, that "we refuse to permit an alien race any influence upon our political, spiritual, or cultural life or to allow an alien any privileged position in the economic sphere."31

Throughout the 1930s, the Nazi regime implemented measures that successively stripped Jews of their legal and economic rights as well as their place within German culture and society. But it was the enactment of the Reich Citizenship Laws of 15 September 1935 that drew the most explicit line between Jews and Germans, unilaterally stripping Jews of their legal status as citizens and thereby definitively removing them, legally and conceptually, from the German political community. Paragraph 2 established the criterion for full citizenship: "a Reich citizen is a subject of the State who is of German or related blood"; "the Reich citizen is sole bearer of full political rights in accordance with the Law." 32 In the First Decree to the Reich Citizenship Law, 14 November 1935, paragraph 4 explicitly disenfranchised Jews: "A Jew cannot be a Reich citizen. He has no voting right in political matters." Departing from Judaism's definition of Jewishness as based on matrilineal descent and embracing instead a racial definition, the decree defined a Jew as "a person descended from at least three Jewish grandparents who are full Jews by race."33

The legal and, more importantly, conceptual framing of the identity of Jews as separate from German and other national identities was not lost on at least some Jews at the time. Reading newspaper reports of the promulgation of the Nuremberg Laws from his vantage point in Vienna, the highly secularized and assimilated future deathcamp survivor Jean Amery (then named Hans Mayer) was immediately struck by the new separate racial identity conferred on him by the Nazi regime. Amery wrote after the war that he "needed only to skim them and already I could perceive that they applied to me. Society, concretized in the National representatives of the German people, had just made me formally and beyond any question a Jew."34 Amery writes that as the Holocaust unfolded he experienced, prior to his deportation and even later in Auschwitz, "the social reality of the wall of rejection that arose before us everywhere." $" 35$ 
Summing up the Nazi regime's steady removal of Jews from German society in the 1930s, Holocaust historian Saul Friedlander suggests that the Nazis doggedly overcame the challenge of separating out a previously assimilated minority:

Among the main obstacles faced by the regime in its attempt to eliminate the Jews from
Germany was the fact that the victims had been part and parcel of every field of activity
in German society. In consequence, if direct violence was not [yet] possible, the system
had to elaborate ever new administrative or legal measures in order to undo, stage by
stage, step by step, the existing ties between society and the Jews. ${ }^{36}$

With the turn toward deportation and concentration during the first years of the war, the Nazi leadership still kept the first conceptual switch on concerning the collective identity of the Jews-even as it moved closer and closer to turning on the second conceptual switch, which would lead from 1941 onward to the annihilation of European Jewry. In the summer of 1941, for example, Joseph Goebbels emphasized the necessity of maintaining the unequal legal and conceptual status of the Jews through their continued removal from Nazi Germany. In a bid to head off criticism of the requirement that German Jews wear the Judenstern (the yellow star), Goebbels, as propaganda minister and Gauleiter of Berlin, argued forcefully that "the Jews had no right to claim equality with us" because "they are Jews who have no right to a voice in the community." 37

In the case of Cambodia, the first-switch dynamic differs in a number of respects from the reconceptualization of German Jews as foreign or alien to German society. The Khmer Rouge period in Cambodia involved the first-switch reconceptualization of not one but several different groups of people at different times for the duration of Khmer Rouge rule. As well, the first-switch conceptualization of the victim groups in Cambodia occurred virtually simultaneously with the second conceptual switch, which further defined these same groups as not only alien to the revolution but also inherently threatening and dangerous. Further, while the victims of the Khmer Rouge were targeted for destruction by means both direct (execution) and indirect (malnutrition, lack of medical care, abuse, etc.), the act of physical separation of the victims did not occur as it did in the Holocaust.

The first-switch reconceptualization of the identity of the various victim groups as outside revolutionary Cambodian society revolved around the Khmer Rouge's own particularly rigid Marxist understanding of Cambodian society as historically and presently divided into antagonistic classes. In the quest for a homogeneous, united, "collective" revolutionary community, classes, ethnic groups, and, eventually, individual cadres and their associates and families deemed suspect were to be overcome and, as Alex Hinton argues, "excluded from the revolutionary community of equals." 38

Using personal histories to categorize Cambodians into revolutionary and reactionary classes served to conceptually and practically divide the society of Democratic Kampuchea into three distinct and separate groups, each with differing levels of membership, or non-membership, in the new revolutionary community. The "new people," mostly urbanites from what were labeled Classes I and II, were nonmembers of revolutionary Cambodia. A 1978 party publication identified the poor peasants as the foundation of the revolution and therefore deserving of the designation "full rights members," while "reactionaries," whose status varied according to the degree to which they were perceived to be naturally hostile to the revolution, were further broken down into three sub-groups: "those who can be drawn to the revolution"; "neutralists, who do not oppose the revolution"; and, in language that 
clearly demonstrates the third-switch conception of the victim group as non-human, "the savage ones who cannot be reeducated." All leadership cadres were instructed to "select and assign by dividing into separate categories full rights, probationary and depositee members," with the latter understood to be the "new people" deported from the cities. The purpose of this exercise was to "clearly distinguish the good from the bad." 39

Just as the Nazis maintained an essentialist understanding of Jews as a "race" that could never be German, the Khmer Rouge made plain its similarly rigid conception of the counterrevolutionary identity of the "new people" and other suspect groups. Members of suspect classes were defined by, and could not overcome, their counterrevolutionary identity. The previous possession of property was said, in a 1976 special issue of the party publication Tung Pradevat ("Revolutionary Flags"), to "obstruct the understanding and the absorption of the Socialist Revolution. No matter how we explain it, the struggle cannot break it out." ${ }^{40}$ Even though these classes had been defeated with the advent of Democratic Kampuchea, "their specific traits and contradictions (tamna) still exist...in consciousness, in standpoint," and, more threateningly, in "class rage." Capitalists, feudal landlords, and petit-bourgeois intellectuals, therefore, still maintained the "essence of class." This essence was "the class standpoint, class character (nissay), sentiments, [and] habits" that "remind[ed] it of the desire to oppress." The article concludes by reinforcing the static nature of counter revolutionary class identity, suggesting that, quite simply, "[a] number of them [vea, literally "things"] cannot be corrected," since they "continuously seek occasions to oppose the revolution." 41

\section{The Second Switch}

\section{The Epic-Battle Motif}

At the heart of much of Nazi ideology were the belief that the world is divided into superior and degenerate races, the need to protect the purity of a people's "blood," and the idea of race wars. This belief applied particularly to the perceived epic struggle between Jews and Aryans. In Mein Kampf, Hitler argued that "the mightiest counterpart to the Aryan is represented by the Jew." ${ }^{2}$ Behind this assertion is a more general understanding that "history itself represents the progression of a people's struggle for survival," in which "life is a never ending battle against death." "I3 If a successful struggle for the preservation of the blood and culture of the German people is not waged against the Jews,

then the Jews can move in, in every form, and this master of international poison concoction and racial debasement will not rest until he has completely uprooted and thereby corrupted such a people. The end, then, is the loss of a certain uniform racial value and thus the final decay... every existing racial value of a people [will become] ineffective-if not downright endangered." ${ }^{4}$

Drawing on these foundational ideas, both Hitler and those of his subordinates most closely involved in the decision, taken in mid-1941, to exterminate Europe's Jews began to describe the Jews as mortal enemies who must be destroyed if the Reich and the German people were to be saved. In a leading article titled "The Jews are Guilty!" published in the Nazi journal Das Reich on 16 November 1941, Goebbels invoked the epic struggle motif, proclaiming that "the Jews are receiving a penalty that is certainly hard, but more than deserved ... and is now gradually experiencing the destruction it planned for us, and would have carried out without a second thought if it had 
possessed the ability." 45 "Every Jew is our enemy in this historic struggle," he warned his readers, whether those Jews lived in the ghettos of Europe or on Wall Street: "All Jews by virtue of their birth and their race are part of an international conspiracy against National Socialist Germany. They want defeat and annihilation, and do all in their power to bring it about."46

In 1942 and 1943, once the genocide was underway, Hitler himself repeatedly referred to his "prophecy," articulated in what has come to be known as his "threat speech" of 30 January 1939, in which he forecast the destruction of European Jewry should the Jews "succeed" in plunging Europe once again into war. But in restating his prophecy, Hitler noticeably changed its language to directly connect the Jews not with starting a new European-wide war that would lead to the "Bolshevization" of Europe, as Hitler had originally warned in January $1939,{ }^{47}$ but with the destruction of the "Aryan race." Thus, on the ninth anniversary of the Nazi seizure of power, Hitler proclaimed, in his address at the Berlin Sportpalast on 30 January 1942,

that the war can only end either with the extermination of the Aryan peoples or the disappearance of Jewry from Europe... [Th] at this [war] will not come to an end as the Jews imagine, with the extermination of the European-Aryan peoples, but that the result of this war will be the annihilation (Vernichtung) of Jewry. For the first time the old Jewish law will now be applied: an eye for an eye, a tooth for a tooth... And the hour will come when the most evil world-enemy of all time will have played out its role, at least for a thousand years. ${ }^{48}$

Like Hitler and Goebbels, Reichsführer-SS Heinrich Himmler similarly argued, in an infamous speech before an assembly of SS officers in Posen in October 1943, the dangers of leaving any Jews alive in Germany and, by extension, in Europe. Seeking to assure his men that their role in the extermination program was a just and noble cause, Himmler stressed that the SS "had the moral right, we had the duty toward our people, to destroy the people that wanted to destroy us." 49

In the Cambodian case, the epic-struggle motif revolved not around race (apart from the Vietnamese) but around the conception of an unending lethal struggle between antagonistic classes. Building and protecting the revolution involved a constant battle to confront inevitable class contradictions and the hidden class "enemies within" they produced-enemies whose goal it was to destroy Democratic Kampuchea, the Communist Party, and the revolution.

Senior Khmer Rouge leaders believed that the recent history of the party was that of a "party led by the working class" steeped in "the contradictions in Kampuchean society," as "Brother Number Two," Nuon Chea, told a Communist Party delegation from Denmark in July 1978. In pre-revolutionary times, the party fought "external contradictions" between the Cambodian nation and "US imperialism" while simultaneously battling "internal contradictions... between, on the one hand the working class and the capitalists and on the other the poor peasants and the feudal class." 50 Among the "new people"-or "new peasants," as the article "Sharpen the Consciousness" calls them-there still existed "life and death contradictions." 51

Making explicit reference to the enduring nature of class struggle between revolutionary and counterrevolutionary forces and, therefore, the continuous threat of internal class enemies to the revolution, a Communist Party document from 3-7 June 1976 notes that while the revolution had defeated many enemies, there will still be many more in the future: "the enemy will carry out activities against us, against our revolution, in various forms. This is the continuous non-stop struggle between revolution and counter-revolution." The document then projects this as a permanent 
state of affairs: "there will be enemies in ten years, twenty years, thirty years into the future...the struggle between revolution and counter-revolution will continue." Noting that not all but some contradictions are created by enemies, the document concludes that "we cannot escape them." ${ }^{52}$ While the party conceded that "it is possible that some compositions [i.e., classes] can correct themselves ... many cannot." Even "if these people die," the revolution will not be safe, since "they will have instructed their children to keep struggling against communists." 53

The enduring nature of the threat posed by ongoing class contradictions was further reinforced in a party study session in 1976, during which the participants were told that the party

must remain vigilant against internal class enemies because our socialist revolutionary direction is an uncompromising, bitter, life-and-death combat between classes, both indirect and most thorough, between the property-less class under the leadership of the Party and the life-and-death enemy who comprises the various exploiting classes... which hide themselves in our revolutionary ranks, in the army, and in the ranks of our Party. ${ }^{54}$

\section{The Foreign-Threat Motif}

The mortal threat posed by Jews as the ultimate leaders of rapacious Bolshevism further solidified the conception of Jews as an all-powerful, inherently dangerous, threatening, and foreign force. Illogically, the Jews were also conceptualized as international capitalists who covertly controlled the Western Allies, secretly pushing Great Britain and the United States to fight another war with Germany. But it was the threat of "Jewish Bolshevism," which surfaced repeatedly in Nazi discourse from the 1920s onward, that contributed to the perception that Jews were a threat like no other, since Nazism and Bolshevism were seen as two competing Weltanschauungen.

In his original "threat speech" at the Reichstag on 30 January 1939, Hitler emphasized the Jews' dangerous capacity for the devious manipulation of international capital and Western governments, to the point of being capable of starting a new world war that, in Hitler's view, would lead, rather nonsensically and paradoxically, to the "Bolshevization" of the world. This overwhelming power and threat posed by the Jews, would, however, be defeated in the most thorough way possible:

If the international Jewish financiers in and outside Europe should succeed in plunging the nations once more into world war, then the result will not be the bolshevization of the earth, and thus the victory of Jewry, but the annihilation of the Jewish race in Europe! ${ }^{55}$

The link between Jews and the threat posed by Soviet Bolshevism was drawn even tighter with the launching of Operation Barbarossa (the invasion of the Soviet Union) and the advent of the genocidal Einsatzgruppen and Sonderkommandos, tasked first with the shooting to death of "commissars" and "Jewish men"- the latter described as the "intellectual reservoir of Bolshevism" by SD chief Reinhardt Heydrich. At a meeting at the headquarters of the Reichssicherheitshauptamt (the Reich's main security office, or RSHA) on 17 June 1941, Heydrich told the assembled Einsatzgruppen, Einsatzkommandos, Sonderkommandos, and other top police officers that "this reservoir must be destroyed." "F6 For Goebbels, meanwhile, the war was the product of an unholy alliance between "Bolshevik Jews" in Moscow and the "Jewish plutocrats" in London and Washington. ${ }^{57}$

During the latter years of the war Goebbels justified the war of extermination in the East, against so-called Jewish Bolshevism, and the Final Solution by explicitly 
tying the survival of the Third Reich to the destruction of the Jews. Goebbels peddled his own particular version of the world Jewish conspiracy theory by arguing that the Allies menacing the Reich from both west and east were operating under the control of world Jewry, bent on the extermination of the German people:

They organized the enemy's war economy and encourage plans to exterminate and destroy the Axis powers. England and the USA recruit from among them bloodthirsty and vengeful agitators and political lunatics and they are the source of the terror commissars of the GPU [the Soviet secret police]. ${ }^{58}$

Near the end of the war, Goebbels went even further, accusing Soviet and Western Allied soldiers of being mercenaries of the Jews. ${ }^{59}$

Like the Nazis, the Khmer Rouge leadership perceived the revolution to be in mortal danger, heightened by the foreign-threat motif; in this case, however, Democratic Kampuchea's many hidden enemies were believed to be stalking horses for foreign influence and invasion whom the party considered, as one document put it, "running dog agents burrowing within ourselves," "international agents," or simply "enemy agents." 60

A radio broadcast on 10 May 1978 named Vietnam and its internal agents explicitly as a mortally threatening enemy that must be neutralized in order to save the "Cambodian race." After calling for the "purification" (a common euphemism, at the time, for mass killing) of the armed forces, the Communist Party, and the masses, the broadcast went on to state that the struggle against internal and external Vietnamese-inspired enemies was vital "in order to continue fighting the enemies in defense of Cambodian territory and the Cambodian race, for if we do not do so, our race will disappear. Do we want to see the end of the Cambodian race? If we do not to defend our territory, we shall lose it, and then our race will also disappear." Should the Vietnamese invade, the broadcast predicted, "we shall lose our territory and our race will be completely swallowed up."61

In a Khmer Rouge document titled "The Last Plan," parts of the "evidence"62 gathered by the party refined the supposed role of Vietnam and those purportedly working covertly for Vietnam inside DK and the party. The Vietnamese communists in Hanoi were said to be the "implementers" of a plot to take over the country and destroy the party. Inside Cambodia, secret "CIA agents" and "Vietnamese expansionists" allegedly cooperated to implement this "scheme in constant contact with the outside." "63 Until the plan was "uncovered," cadres involved in its implementation had worked for years to create internal divisions in order to weaken all parts of the party. The ultimate goal of the "men who were hiding inside" was to "join hands to smash all sides thus winning the power forever, particularly definitely abolishing communism."64

According to the Khmer Rouge, Democratic Kampuchea's alleged enemies were not all doing the bidding of the Vietnamese. In his confession-through-torture before execution, senior moderate cadre $\mathrm{Hu}$ Nim "confessed" to being recruited as a CIA member to conduct subversive activities within the party as early as 1957. His task was "to bring outsiders inside the Communist Party of Kampuchea in order to destroy it from within" and "to change the line of the [party]... and the revolutionary movement" toward "revisionism," because "revisionism is the way toward capitalism anyway." 65

Without discussing when it would have happened or under what circumstances, Nuon Chea suggested in 1978 that some cadres had been imprisoned by the offending foreign powers and, like the Manchurian Candidate, tortured and turned into enemy 
agents who were unwittingly accepted back into the party—but "we now realized they had become agents of the enemy." Although a "plot" by the United States to take over DK Cambodia with the help of the Vietnamese and the KGB six months after liberation was apparently foiled, Nuon Chea asserted that the Khmer Rouge must "apprehend the people who have infiltrated our party. We know the current plan involves not only Vietnamese agents, but has something to do with US imperialism and the KGB. All of them!"66

\section{The Biological-Contagion Motif}

The final mortal-threat conception, the motif of biological contagion, identified Jews as a deadly, opportunistic infectious agent that threatened the purity of German blood and society with disease and death. The future health and strength of the Aryan or Nordic race could be ensured only through the destruction of what threatened it most: the Jews.

From the early 1920s onward, Hitler's public discourse about the Jews was riddled with references to the Jews as a "plague" and "a harmful bacillus."67 Mein Kampf likens the Jews to

the typical parasite, a sponger who like a noxious bacillus keeps spreading as soon as a favorable medium invites him [in]. And the effect of his existence is also like that of spongers: wherever he appears, the host people dies out after a shorter or longer period. $^{68}$

Other Nazi leaders evinced the same perception of Jews as a lethal contagion. Just after the invasion of Poland, Goebbels is reported to have commented to his officials that he believed the Jews "represented an international infection, and that it will fight against the state of order until it controls them." During the "abnormal times in the life of a nation at war," Goebbels was "convinced that we cannot allow Jewry, as a seat of infection, to exist any longer." He argued that there "can be no more discussion in Germany of the necessity of removing Jewry as a seat of infection. The vast majority of the German nation want a total solution to the Jewish question."69

For the Nazi leadership, therefore, the Jews were a deadly pestilence that had to be physically removed from the European body politic. Goebbels thus invoked the specter of deadly disease and the metaphorical medical procedures required for dealing effectively with the threat posed by the Jews: "Our task here is surgical...drastic incisions or some day Europe will perish of the Jewish disease."70 On 23 July 1941, Hitler similarly referred to the Jews, in a conversation with Croatian Marshal Kvaternik, as "a centre of pestilence for humanity." Without giving any details, Hitler assured Kvaternik that all Jews were going to be removed from Europe and warned that any state that retained Jews would invariably become a new source of infection and decomposition. ${ }^{71}$

For the Khmer Rouge, the motif of biological contagion was invoked repeatedly as the revolution's internal enemies were labeled "microbes" or sources of contamination or poison, "burrowing within the revolution" to destroy it from the inside out. One Communist Party report called for "continuous measures" to be taken so that "enemies will not be able to advance, using venom and poison." "72 Using almost identical language, a 1977 Central Committee document emphasizes that "[b]y screening traitorous elements and bad elements, the party enjoys relief from [the] pain and abscess [and] venom" caused by internal party enemies. ${ }^{73}$ Switching to a related hygiene metaphor, cadres were reminded at a study session in 1976 to remain vigilant against enemies but were told that the party had already taken 
effective measures: "We have been scrubbed clean [another euphemism for mass murder] and nurtured in political standpoint, consciousness, and organization."74

The most explicit formulation of the victims-as-disease threat motif was articulated by Pol Pot in the threatening end of his 1977 "microbes" speech, which, in effect, signaled the genocidal intraparty purge to come:

While we are engaged in a socialist revolution, there is a sickness inside the Party, born in the time when we waged a people's and a democratic revolution. We cannot locate it precisely. The illness must emerge to be examined. Because the heat of the people's revolution and the democratic revolution were insufficient at the level of the people's struggle and at the level of class struggle among all layers of the national democratic revolution, we search for the microbes within the Party without success. They are buried. $^{75}$

Echoing Goebbels' reference to surgical cuts to eliminate poisonous European Jewry, the Khmer Rouge, according to one survivor,

justified destruction of "diseased elements" of the old society....We were told repeatedly that in order to save the country, it was essential to destroy all contaminated parts.... It was essential to cut deep, even to destroy a few good people rather than chance one "diseased" person escaping eradication. ${ }^{76}$

The conception of the enemy as an unseen but ever-present disease infecting the party and the revolution contributed greatly to the constructed nature of the victims of the Cambodian genocide. Since the enemy was unseen but present, it could take almost any form, even appearing to be loyal to the cause or of proper class background, yet be on the inside a source of counter-revolutionary contagion. The fluid nature of the construction of the victims' collective identity led the genocide-at first inflicted on elements of the old regime, on ethnic minorities, and on clearly defined class enemies such as the "new people"-to turn inward and become a genocidal internal party purge.

\section{The Third Switch}

Holocaust survivors have noted that low-level perpetrators in the ghettos and the camps saw Jews not as human but as animals, or even less than that. ${ }^{77}$ The public dehumanization of Jews began soon after the Nazis came to power. Boasting of the alleged success of the boycott of local Jewish businesses, a participant at a conference for German civil servants told his audience that Jews should not be surprised by the boycott, since "when you, Jew, regard us as a beast, do not expect us to treat you like a human being."78 Heydrich, a central figure in the planning and perpetration of the genocide until his assassination in 1942, characterized Jews to his fellow SS officers in January 1939 as "the eternal subhumans." 79 In a tour of newly occupied Poland in September 1939, Himmler, Heydrich's superior, later recounted to other SS officers how he had summoned a few of the "criminal specimens" to show colleagues traveling with him a sick elderly Jewish man's bone structure, calling the old man, and all Ostjuden (eastern Jews), "vermin." ${ }^{80}$ After a similar junket to the Lodz ghetto in the General Government, Goebbels reportedly told Hitler of his visit: "It's indescribable. Those are no longer human beings. They are animals." 81 The following year Himmler told an audience in Krakow that "anti-Semitism is exactly the same as delousing. Getting rid of lice is not a question of ideology. It is a matter of cleanliness." 82

The advent of the death camps and the industrialized killing of Jews in gas chambers was, in part, a means of relieving the psychological burden on the low-level 
perpetrators of killing their victims face to face. But the death camps also served as a means by which the victims could be completely dehumanized before their deaths, making their killing by gassing, medical experimentation, starvation, abuse, or disease a psychologically acceptable task. ${ }^{83}$ For some death-camp commanders, the dehumanization of Jewish prisoners through humiliation was necessary in order for the low-level perpetrators to operate the industrial machinery of death. When asked by a post-war interviewer, "If they were going to kill them anyway what was the point of all the humiliation, why all the cruelty?" the Kommandant of Treblinka, Franz Stangl, replied, "To condition those who actually had to carry out the policies. To make it possible for them to do what they did." 84 In a statement that seems to reveal that Stangl's approach worked on at least some frontline perpetrators, Order Policeman Alois Hafele, a guard at the Chelmno death camp, told a superior in 1943 that he had become used to the killing: "Little men or little women, it was all the same, just like stepping on a beetle." As Hafele spoke, he reportedly made a scraping motion with his foot on the floor. ${ }^{85}$

The victims in the camps were also keenly aware of their own dehumanization. In his painful recollections of the Muselmänner ${ }^{86}$ who haunted his memories years after his liberation from Auschwitz, Primo Levi describes the completely dehumanized state in which these "drowned" men existed:

Their life is short, but their number is endless; they, the Muselmänner, the drowned, form the backbone of the camp, an anonymous mass, continually renewed and always identical, of non-men who march and labour in silence, the divine spark dead within them, already too empty to really suffer. One hesitates to call them living: one hesitates to call their death death, in the face of which they have no fear, as they are too tired to understand. ${ }^{87}$

In Cambodia the refrain "to keep you is no gain, to kill you is no loss," constantly repeated by the Khmer Rouge to the regime's victims, clearly indicated the degree to which individual human life had become devalued and easy to extinguish. In his analysis of the orientation Khmer Rouge cadres adopted toward the urban populations of Phnom Penh and other cities, David Chandler suggests that the dehumanization of the "new people" was almost immediate. The rural cadres who took over and emptied the cities saw urban dwellers as "enemies," to be "treated as they deserved. Overnight they became 'new people' or 'April 17 people'-less than human, without privileges or rights." 88

In everyday discourse, the victims of the Khmer Rouge were addressed by the dehumanizing vulgar noun vea ("it" or "thing," normally used for inanimate objects and for animals). Ethnic minority victims of the genocide were similarly addressed; the Vietnamese were frequently referred to by the pejorative yuon ("savage"). Such modes of discourse dehumanized those deemed to be non-members of the revolution and, as Hinton argues, helped legitimize - and, one could add, facilitate_violence against the victims. $^{89}$

The dehumanization of victims in the service of death in Cambodia reached its nadir at the Tuol Sleng torture and execution facility, located in a former high school in Phnom Penh. Articulating the party leadership's conception of their enemies as subhuman, former senior party cadre $\mathrm{Hu}$ Nim was tortured into proclaiming, in his extracted confession, "I am not a human being. I am an animal." 90 Recalling the appallingly brutal torture he and other inmates endured at Tuol Sleng, survivor Vann Nath said in an interview after the genocide that the prisoners were treated as if they were "worth less than an animal to them... They didn't treat us like people.""1 
The ability to treat perceived enemies as subhuman was learned early by many Khmer Rouge cadres, even before the victory in 1975. Many of these cadres were recruited at a very young age from the nomadic hill tribes of the remote northeastern provinces of Ratanakiri and Mondolkiri, where isolated Khmer Rouge camps were located during the latter Sihanouk years at the beginning of the civil war. By exploiting these impoverished, illiterate youths' resentment of prosperous city dwellers and the fact that they had no stake in the pre-revolutionary system, the Khmer Rouge leadership, as Karl Jackson suggests, "sought out those from the bottom rung of society-those who were so envious of persons with more wealth that they would willingly strike them down." 92 The teenage cadres were taken from their families, treated brutally by their superiors, and then given what the Communist Party said was the great honor of becoming Oppakar Phdach Kar Robas Pak, literally "the dictatorial instrument of the Party."

In this element of the third switch, then, we see a contrast with the Nazi final solution. In Cambodia, both dehumanizing discourse and the dehumanization of the perpetrators facilitated killing through execution, abuse, and neglect of the regime's victims. In the Nazi case, the explicitly dehumanizing discourse directed at the Jewish victims was also present, while the projection of the dehumanized state of the low-level perpetrators onto the victims was not. In fact, the SS, which bore the primary responsibility for executing the genocide on the ground, was billed by Himmler as an elite corps of the most racially pure Aryans in the Reich, the "hardest of the hard men," who had been given the bloody but noble task of riding the Reich and Europe of the subhuman Jewish race.

\section{Conclusion}

The preceding discussion of the importance of collective identity reconstruction and elite decision making can help us to fill in a piece of the larger "why genocide" puzzle raised at the beginning of this essay in three ways. First, it focuses our analysis on a small but key group of actors in the genocidal process, without whom genocide would not be possible. It is, after all, these elite actors who make the decision to commit genocide. In order to understand why elite perpetrators choose genocide as a policy option, we need to go beyond considering general precursors, triggers, and general conceptions of blame, threat, and dehumanization attached to the victim group. To complete the picture, we need to account for how elite perpetrators conceptualize the identity of the victim group such that genocide comes to be seen as the only possible policy response.

Second, an emphasis on collective identity construction is useful because it also allows us to further explore the answer to the "smaller" questions noted above. The relationship between structure (both ideational and material) and collective identity reconstruction by elite and societal actors (the latter of which is not examined here but is of central importance) points to the significance of the precursors to genocide and how they directly influence the genocidal decision-making process. As is outlined only briefly in this article, pre-genocide norms and practices that include unequal and exclusionary relationships between the eventual victim group and the rest of society, exclusionary conceptions of who constitutes the genuine membership of the political community, and authoritarian and sometimes violent methods of conflict management by the state directly influence how, in the wake of crises, elite actors reconceptualize (and how the dominant society comes to accept) the identity of the victim group as a mortal threat and why specific groups are targeted for genocide while others are not. As for the perpetrators and why they do what they do, identifying the three conceptual 
switches of genocide allows us to differentiate the motivation for genocide- the second mortal-threat conception of the victim group that leads elite perpetrators to chose a policy of genocide-from the dehumanization of the victim group that allows both elite and frontline perpetrators to actually carry out the extermination of objectively innocent and powerless human beings.

Finally, the case-study comparison suggests that the collective identity reconceptualization process that underpins the decision to commit genocide is common across relatively dissimilar cases and that, therefore, this process is likely common to most genocides in the twentieth and twenty-first centuries. The model offered here is not a predictive social-science theory. Rather, it tries to offer some insight into mutually constitutive relationship between ideational structures (norms) and material structures (practices and crises), on the one hand, and the genocidal process of reconceptualizing the victim group, on the other, as the foundation for elite decision making. The emphasis, then, is on a set of general structures and processes that get at the underlying logic of genocide and thus can tell us, albeit only partly, why something so terrible as genocide happens.

\section{Notes}

1. Mark Blyth notes in a recent article that, at least where comparative politics is concerned, successive "grand theories" in the discipline have failed to predict and explain the occurrence of several political, social, and economic "great punctuations" since the advent of the discipline in the early twentieth century. Mark Blyth, "Great Punctuations: Prediction, Randomness, and the Evolution of Comparative Political Science," American Political Science Review 100 (2006): 493-98.

2. See, e.g., Ervin Staub, The Roots of Evil: The Origins of Genocide and Other Group Violence (Cambridge: Cambridge University Press, 1989), 13-55; Israel W. Charny, How Can We Commit the Unthinkable? Genocide, the Human Cancer (Boulder, CO: Westview Press, 1982), 107-10; Florence Mazian, Why Genocide? The Armenian and Jewish Experience in Comparative Perspective (Ames: University of Iowa Press, 1990), 243-47; Manus I.

Midlarsky, The Killing Trap: Genocide in the Twentieth Century (Cambridge: Cambridge University Press, 2005), 83-110.

3. Despite the fact that the Final Solution and the Cambodian genocide are both cases of genocide, they are, as noted, relatively dissimilar ones. It is because of their dissimilarities that these two cases have been selected to illustrate the proposed explanatory model. The comparison is what political scientists Adam Przeworski and Henry Teune call a "most different" comparison. Although Przeworski and Teune advocate for "most similar" comparisons in order to control for as many variables as possible, a "most different" approach is useful for the comparative analysis of genocide. This is so because each case of genocide is marked by it own horrible uniqueness; as a result, we are unlikely to find exactly equivalent cases. Genocides vary, across time and space, in terms of who the victim groups are and what methods of destruction are employed, not to mention the particular individual and collective manifestations of the suffering of victim groups, the brutality of perpetrators, and the indifference of bystanders. A "most different" comparison is, in a sense, the only kind available to us. It also allows us to acknowledge, and to treat seriously, the great variety among genocides, while still attempting to locate what is fundamental to all or most genocides, in terms of both the preconditions for and the actual perpetration of genocidal mass murder. Adam Przeworski and Henry Teune, The Logic of Comparative Social Inquiry (New York: Wiley, 1970).

4. Helen Fein, Accounting for Genocide: National Responses and Jewish Victimization during the Holocaust (New York: Free Press, 1979), 7-8. For other scholars who understand genocide as a rational choice made by elites, see Peter du Preez, Genocide: The Psychology of Mass Murder (London: Boyars/Bowerdean, 1994), 3; Roger W. Smith, "State, Power, and 
Genocidal Intent: On the Uses of Genocide in the Twentieth Century," in Studies in Comparative Genocide, ed. Levon Chorbajian and George Shirinian, 3-14 (New York: St. Martin's Press, 1999).

5. Benjamin A. Valentino, Final Solutions: Mass Killing and Genocide in the 20th Century (Ithaca, NY: Cornell University Press, 2004), 4, 72-73.

6. Valentino rejects the concept of genocide as "too limiting" for his analysis.

7. Valentino, Final Solutions, 5.

8. William H. Riker, "The Political Psychology of Rational Choice Theory," Political Psychology 16 (1995): 24-26.

9. Ibid.

10. "May" is the operative word here. Several laboratory studies performed on test subjects, as well as analyses of real-world political and other actors, have demonstrated that actors are frequently incapable of ordering their preferences effectively or of calculating subjective expected utility, particularly in crisis situations. See, for example, Amos Tversky and Daniel Kahneman, "Rational Choice and the Framing of Decisions," Journal of Business 59 (1986): S251-77; Michael Nicholson, Rationality and the Analysis of International Conflict (Cambridge: Cambridge University Press, 1992); Donald P. Green and Ian Shapiro, Pathologies of Rational Choice Theory: A Critique of Applications in Political Science (New Haven, CT: Yale University Press, 1994).

11. Robert F. Melson, Revolution and Genocide: On the Origins of the Armenian Genocide and the Holocaust (Chicago: University of Chicago Press, 1992).

12. Eric D. Weitz, A Century of Genocide: Utopias of Race and Nation (Princeton, NJ: Princeton University Press, 2003).

13. Alex Alvarez, Governments, Citizens, and Genocide: A Comparative and Interdisciplinary Approach (Bloomington: Indiana University Press, 2001).

14. Christopher R. Browning, The Origins of the Final Solution: The Evolution of Nazi Jewish Policy, September 1939-March 1942 (Lincoln: University of Nebraska Press/Jerusalem: Yad Vashem, 2004).

15. James Waller, Becoming Evil: How Ordinary People Commit Genocide and Mass Killing (Oxford: Oxford University Press, 2002).

16. Alexander Wendt, "Anarchy Is What States Make of It: The Social Construction of Power Politics," International Organization 26 (1992): 391-425.

17. Alexander Wendt, "Constructing International Politics," International Security 20 (1995): 73-75.

18. Alexander Wendt, Social Theory of International Relations (Cambridge: Cambridge University Press, 1999), 24.

19. Ibid., 119.

20. Roy D'Andrade, "Schemas and Motivation," in Human Motives and Cultural Models, ed. Roy D'Andrade and C. Strauss, 23-44 (Cambridge: Cambridge University Press, 1992), 28, quoted in Wendt, Social Theory, 122.

21. Wendt, Social Theory, 330.

22. Ibid., 330-31.

23. Ibid., 335 .

24. For a detailed discussion of the relationship between pre-genocide exclusionary and authoritarian norms and practices, crisis, and collective identity reconstruction in genocide, see Maureen S. Hiebert, "Origins of Genocide: Political Culture, Crisis, and the Construction of Victims" (PhD diss., University of Toronto, 2007).

25. Fein argues that a necessary precondition of genocide is the conceptualization of the victim group as existing outside the community. She argues, with reference to the Armenian Genocide and the Holocaust, that in both cases the victim group was decreed historically by the dominant group to be "outside the sanctified universe of obligation-that circle of people with reciprocal obligations to protect each other whose bonds arose from their relation to a deity or sacred source of authority. In the modern secular era, this traditional history of exclusion from the religious and social order allows for the modern definition 
of these same groups as strangers by virtue of the fact that the dominant group was already alienated from the victim group by traditional antipathies." Fein, Accounting for Genocide, 4-5. In the theoretical approach presented here, the exclusion of the victim is only the first phase of the genocidal process, because Fein's approach on its own does not explain why extermination is chosen over other policies, such as expulsion, forced assimilation, re-education, or the use of violence that stops short of genocide.

26. Daniel Chirot and Clark McCauley, Why Not Kill Them All? The Logic and Prevention of Mass Murder (Princeton, NJ: Princeton University Press, 2006), 31.

27. Robert Jay Lifton, The Nazi Doctors: Medical Killing and the Psychology of Genocide (New York: Basic Books, 1986), 477.

28. Ibid., 479.

29. Herbert C. Kelman, "Violence without Moral Restraint: Reflection on the Dehumanization of Victims by Victimizers," Journal of Social Issues 29, no. 4 (1973): 48-49.

30. Adolf Hitler, "Closing Speech at the Nuremberg Parteitag 1938, 12 September 1938," in The Speeches of Adolf Hitler, 1922-1939, ed. and trans. Norman H. Baynes, vol. 1 (London: Oxford University Press, 1978), 735.

31. Adolf Hitler, "Speech Before the Reichstag, 30 January 1937," in The Speeches of Adolf Hitler, 1922-1939, ed. and trans. Norman H. Baynes, vol. 1 (London: Oxford University Press, 1978), 735. The idea of separating Jews from Germans came out of the earliest party platforms of the Nazis in the 1920s. Prefiguring the administrative measures taken against German Jews in the 1930s, the völkisch newspaper Völkischer Beobachter published a diatribe against the supposed evils of the Ostjuden (Eastern European Jews) on 10 March 1920 that ended with the party calling for the immediate removal of Jews from all government employment, newspapers, theaters, and cinemas.

32. "Reich Citizenship Laws" (15 September 1935), trans. Ronnie Landau, in The Nazi Holocaust, by Ronnie Landau (Chicago: Ivan R. Dee, 1994), Appendix E, 310.

33. "First Decree to the Reich Citizenship Law" (14 November 1935), trans. Ronnie Landau, ibid., 311. The remainder of paragraph 5 discusses the legal status of Mischlinge, or "half Jews."

34. Jean Amery, At the Mind's Limits: Contemplations by a Survivor on Auschwitz and Its Realities, trans. Sidney Rosenfeld and Stella P. Rosenfeld (Bloomington: Indiana University Press/United States Holocaust Memorial Museum, 1980), 85.

35. Ibid., 87-88. Perhaps projecting his later experiences during the Holocaust and what he called "my resentments" after liberation back in time, Amery contends that, from 1935 onward, to be a Jew meant for him "to be a dead man on leave, someone to be murdered, who only by chance was not yet where he properly belonged." For Amery, the Nuremberg Laws were not simply a means of excluding Jews from German society but "a death threat" that he felt "with complete clarity." Ibid., 86.

36. Saul Friedlander, Nazi Germany and the Jews, Vol. 1: The Years of Persecution, 1933-1939 (New York: HarperCollins, 1997), 203.

37. Joseph Goebbels, "Mimicry," trans. by Randall Bytwerk from Die Zeit ohne Beispiel (Munich: Zentralverlag der NSDAP, 1941), http://www.calvin.edu/academic/cas/gpa/ goeb18.htm (accessed 2 January 2008), 3.

38. Alexander Laban Hinton, Why Did They Kill? Cambodia in the Shadow of Genocide (Berkeley and Los Angeles: University of California Press, 2005), 189, 191.

39. "Pay Attention to Pushing the Work of Building the Party and People's Collective Strength Even Stronger," trans. Kem Sos and Timothy Carney, Tung

Pradevat [Revolutionary Flags] 3 (March 1978): 37-53, in Cambodia, 1975-1978:

Rendezvous with Death, ed. Karl D. Jackson (Princeton, NJ: Princeton University Press, 1989), 297.

40. "Sharpen the Consciousness of the Proletarian Class to Be as Keen and Strong as Possible," trans. Kem Sos and Timothy Carney, Tung Pradevat, September-October 1976, 33-97, in Jackson, ibid., 270.

41. Ibid., 280. 
42. Adolf Hitler, Mein Kampf, trans. Ralph Manheim (New York: Houghton Mifflin, 1999), 300.

43. Adolf Hitler, Hitler's Second Book: The Unpublished Sequel to Mein Kampf, ed. Gerhard L. Weinberg, trans. Krista Smith (New York: Enigma Books, 2003), 7.

44. Ibid., 33.

45. Joseph Goebbels, "The Jews are Guilty!" trans. by Randall Bytwerk from "Die Juden sind schuld!" in Das eherne Herz, 85-91 (Munich: Zentralverlag der NSDAP, 1943), http://www.calvin.edu/academic/cas/gpa/goeb1.htm (accessed 2 January 2008), 1.

46. Ibid.

47. Throughout the war Hitler noticeably changed the date of his original "prophecy" from 30 January 1939 to 1 September 1939. By changing the date to that of the invasion of Poland and the beginning of the war in Europe, Hitler firmly tied the outbreak of war to the threat posed by the Jews.

48. Quoted in Ian Kershaw, Hitler 1936-1945: Nemesis (London: Allen Lane, 2000), 494.

49. Heinrich Himmler, "From a Speech by Himmler Before Senior SS Officers in Poznan, October 4, 1943" (Document no. 161), in Documents on the Holocaust, Selected Sources on the Destruction of the Jews of Germany and Austria, Poland and the Soviet Union (Jerusalem: Yad Vashem, 1981), 344-45, http://www1.yadvashem.org/odot_pdf/ Microsoft\%20Word\%20-\%204029.pdf (accessed 2 January 2008), 1.

50. Nuon Chea, "Statement of the Communist Party of Kampuchea to the Communist Workers' Party of Denmark, July 1978," trans. Peter Bischoff, ed. Laura Summers, in Searching for the Truth [Khmer version] 17 (May 2001), Documentation Center of Cambodia, http://www.dccam.org/Archives/Documents/DK_Policy/

DK_Policy_Noun_Chea_Statement.htm (accessed 2 January 2008), 1.

51. "Sharpen the Consciousness," quoted in Jackson, Cambodia, 1975-1978, 298.

52. "Excerpted Report on the Leading Views of the Comrade Representing the Party Organization at the Zone Assembly," Tung Pradevat, 3-7 June 1976, trans. Ben Kiernan, in Pol Pot Plans the Future: Confidential Leadership Documents from Democratic Kampuchea, 1976-1977, ed. David Chandler, Ben Kiernan, and Chanthou Boua, 13-30 (New Haven, CT: Yale Centre for International and Area Studies, Yale University, 1988), 16.

53. "Sharpen the Consciousness," quoted in Jackson, Cambodia, 1975-1978, 278.

54. "Summary of the Results of the 1976 Study Session" (Party Centre, n.d.), trans. Ben Kiernan, in Pol Pot Plans the Future: Confidential Leadership Documents from Democratic Kampuchea, 1976-1977, ed. David Chandler, Ben Kiernan, and Chanthou Boua, 168-76 (New Haven, CT: Yale Centre for International and Area Studies, Yale University, 1988), 169-70.

55. Adolf Hitler, "Speech to the Reichstag, 30 January 1939," in The Speeches of Adolf Hitler, 1922-1939, ed. and trans. Norman H. Baynes, vol. 1 (London: Oxford University Press, 1978), 741. References to this prophecy/threat above are to later, more explicitly genocidal versions of the prophecy articulated by Hitler and other Nazi elites in the 1940s; here the reference is to the original prophecy, which concentrated on the "Bolshevik" conception of the Jews. As noted above, in later versions of the "prophecy" the threat of "Bolshevization" at the hands of European Jewry was replaced by the threat of extermination of the "Aryan race" by the Jews.

56. Walter Blume, interrogation (29 June 1947), NA RG 238 M-10 19/R7/848, cited in Richard Breitman, The Architect of Genocide: Himmler and the Final Solution (New York: Alfred A. Knopf, 1991), 164. The so-called commissar order, ordering the mass shooting of Soviet commissars and Jewish men, issued soon after was later informally expanded to include all Jewish women and children in Nazi-occupied Soviet territory.

57. Goebbels, "Mimicry," 2.

58. Joseph Goebbels, "The War and the Jews," trans. from "Der Krieg und die Juden," in Der steile Aufstieg, 263-70 (Munich: Zentralverlag der NSDAP, 1944), http://www.calvin.edu/academic/cas/gpa/goeb37.htm (accessed 3 January 2008), 1. 
59. Joseph Goebbels, "The Creators of the World's Misfortune," trans. from "Die Urheber des Unglucks der Welt," Das Reich (21 January 1945), 1+, http://www.calvin.edu/academic/ cas/gpa/goeb64.htm (accessed 3 January 2008), 2.

60. "Letter of Honorary Red Flag from Community Party of Kampuchea's Central Committee to Male and Female Cadres and All Cooperative Farmers in the Districts of Prasat, Campong Tralach and Tram Kak" (1977), trans. (unofficially) Bunsou Sour (Documentation Center of Cambodia), http://www.dccam.org/Archives/Documents/ Red_Flag/Red_Flag_Honoray_to_Central_Committee.htm (accessed 21 January 2008), 7-9.

61. Excerpts from Phnom Penh Home Service, "Cambodia's Strategy of Defence against Vietnam," 1100 GMT, 10 May 1978 (Documentation Centre of Cambodia, FE/5813/A3/1), http://www.dccam.org/Archives/Documents/DK_Policy/DK_Policy_Cam_Defence_VN.htm (accessed 21 January 2008), 1.

62. This so-called evidence consisted of false confessions extracted under torture.

63. "The Last Plan: Summary of Answer [sic] by Chhuk, Secretary of Sector 24 on 23 September 1976 and of the 19th Answer by the Same Person Written on 23 September 1976," in Cambodia, 1975-1978: Rendezvous with Death, ed. Karl D. Jackson, 299-314 (Princeton, NJ: Princeton University Press, 1989), 299.

64. Ibid., 305.

65. Hu Nim, "Planning the Past: The Forced Confessions of Hu Nim," in Pol Pot Plans the Future: Confidential Leadership Documents from Democratic Kampuchea, 1976-1977, ed. David Chandler, Ben Kiernan, and Chanthou Boua, 227-317 (New Haven, CT: Yale Centre for International and Area Studies, Yale University, 1988), 246.

66. Nuon Chea, "Statement of the Communist Party of Kampuchea," 10.

67. Eberhard Jackel, Hitler's World View: A Blueprint for Power (Cambridge, MA: Harvard University Press, 1981), 57.

68. Hitler, Mein Kampf, 305.

69. "Internal Memorandum Regarding the Solution of the 'Jewish Question,' Quoting Utterances Made by Goebbels on This Issue (not dated, apparently Berlin 1939)," Shoah Resource Centre, Yad Vashem Archives, TR2/N11/1009/NG1531, http://www1.yadvashem. org/odot_pdf/Microsoft\%20Word\%20-\%205607.pdf (accessed 21 January 2008), 1. It is important to note that at this time Goebbels was likely not talking about genocide as a "total solution" but, rather, referred to concentration and deportation.

70. Quoted in Rolf Hochhuth, A German Love Story (Boston: Little, Brown, 1980), 18.

71. Klaus Hildebrand, The Third Reich (London: Allen \&Unwin, 1984), 69.

72. "Excerpted Report," 16.

73. "Letter of Honorary Red Flag," 14. Although it is not stated explicitly, we can assume that "screening," in this context, likely means the detention, torture, and execution of suspect cadres.

74. "Summary of the Results," 168.

75. "Report on Activities," in Pol Pot Plans the Future: Confidential Leadership Documents from Democratic Kampuchea, 1976-1977, ed. David Chandler, Ben Kiernan, and Chanthou Boua, 177-212 (New Haven, CT: Yale Centre for International and Area Studies, Yale University, 1988), 183.

76. Teeda Mam Butt, To Destroy You Is No Loss: The Odyssey of a Cambodian Family (New York: Atlantic Monthly Press, 1987), 153-54.

77. Noting the extent to which Jews were perceived as subhuman and treated as such in the camps, one Jewish prisoner doctor said of the infamous Dr. Josef Mengele that "he really hated us" and "treated Jews like laboratory animals-not quite human," because "we were biologically inferior in his eyes." Interview quoted in Lifton, Nazi Doctors, 378.

78. "The German Jewish Press Reports about Anti-Jewish Incitement in the Summer of 1935 (1)" (Judische Rundschau, 2 July 1935), Yad Vashem Archive, Documents on the Holocaust, http://www1.yadvashem.org/odot_pdf/Microsoft\%20Word\%20-\%206572.pdf (accessed 21 January 2008). 
79. Reinhardt Heydrich (24 January 1939), NARG242, T-175/R17/2520613, quoted in Breitman, Architect of Genocide, 59. Breitman notes that this particular phrase became widely used in SS circles after 1941, when the execution of the Final Solution began.

80. Quoted in Breitman, Architect of Genocide, 74.

81. Quoted in Kershaw, Hitler 1936-1945, 249.

82. Heinrich Himmler, "Speech of the Reichsfuehrer-SS Himmler at Kharkow April 1943," partial translation of document 1918-PS, in Nazi Conspiracy and Aggression, vol. 4, 572-78 (Washington, DC: US GPO, 1946), http://www.ess.uwe.ac.uk/genocide/SS3.htm (accessed 21 January 2008).

83. For a philosophical treatment of the dehumanizing effect of the death camps, see Hannah Arendt, The Origins of Totalitarianism (New York: Harcourt Brace, 1979), 438; Theodor Adorno, Negative Dialectics (New York: Continuum, 1994), reprinted in A Holocaust Reader: Responses to the Nazi Extermination, ed. Michael L. Morgan, 42-47, (Oxford: Oxford University Press, 2001), 43.

84. Quoted in Emil L. Fackenheim, "The Holocaust and Philosophy," Journal of Philosophy 82 (1985): 505-14.

85. "Indictment of Gustav Laabs and Alois Hafele" (Bonn, 25 July 1962), 8Js 180/61, quoted in Raul Hilberg, Perpetrators, Victims, Bystanders: The Jewish Catastrophe 1933-1954 (New York: Aaron Asher Books, 1992), 34.

86. Literally "Muslims" in German. Muselmänner was the name used by inmates to describe "the weak, the inept, those doomed to selection." Primo Levi, Survival in Auschwitz, trans. Stuart Woolf (New York: Simon \& Schuster, 1996), 88.

87. Ibid., 90 .

88. David P. Chandler, Brother Number One: A Political Biography of Pol Pot, rev. ed. (Boulder, CO: Westview Press, 1999), 103.

89. Hinton, Why Did They Kill? 191.

90. Hu Nim, "Planning the Past," 239.

91. Vann Nath, interview with Alex Hinton, in Hinton, Why Did They Kill? 191.

92. Kenneth Quinn, "Explaining the Terror," in Cambodia, 1975-1978: Rendezvous with Death, ed. Karl D. Jackson, 215-40 (Princeton, NJ: Princeton University Press, 1989), 236. 